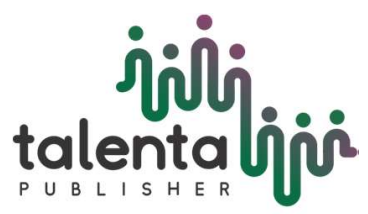

\title{
The Optimization of Pudding Formulation Using Noni (Morinda citrifolia L.) Seen from Antioxidant Content and Sensory Characteristics
}

\author{
Kristiawan Prasetyo Agung Nugroho', Monika Rahardjo', and Apfia \\ Jovitatera ${ }^{1}$
}

${ }^{I}$ Nutrition Study Program, Faculty of Medicine and Health Science, Universitas Kristen Satya Wacana ${ }^{2}$ Food Technology Study Program, Faculty of Medicine and Health Science, Universitas Kristen Satya Wacana

\begin{abstract}
Noni (Morinda citrifolia L.) is a fruit that known to be effective against many diseases. It is phenol and flavonoid content acted as antioxidant, anticancer, antiinflamation and to fluent the blood vessel. It is rich in antioxidant compound, so that this research aims to utilize it as a food product. Pudding is one of food product that categorized as a dessert, which in the production does not require heat treatment, so the antioxidant can be maintained. The purpose of this experiments were to determine the antioxidant content of Noni fruit and to find the optimum formulation of Noni pudding based on sensory characteristics. The method of this research was experiment with sample analysis using total phenolic assay, total flavonoid assay and sensory evaluation by 50 random panelists. The result showed that Noni fruit has total phenolic $0.13423 \mathrm{mg} \mathrm{GAE} / \mathrm{ml}$ and the total flavonoid $0.11819 \mathrm{mg} \mathrm{GAE} / \mathrm{mL}$. The optimum formulation of pudding result from sensory evaluation was found with the addition of $10 \%$ of Noni extract.
\end{abstract}

Keywords: flavonoid, Noni, phenol, pudding, sensory

Received 04 December 2018 | Revised 14 February 2019 | Accepted 18 February 2019

\section{Introduction}

Noni (Morinda citrifolia L.) is a fruit that less favored by peoples due to the unpleasant aroma and texture. All part of Noni plants can be used, such as seeds, leaves, flowers, fruits, skin, and even the roots [1]. Noni fruit has a bad smells. The aroma of Noni is caused by the components such as capric acid, caprylic acid and caproic acid [2]. The texture of Noni fruit is soft and fibrous. Noni fruit has bitter flavor, so many people do not like it. However, Noni fruit has many benefits on health, and therefore it become very popular in the Caribbean, Asia Pacific and Southeast Asia for medicine treatments [3]. Noni fruit has antioxidant with function as herbal medicine or alternative medicine to overcome various diseases. Noni fruit had a high antioxidant compound.

*Corresponding author at: Nutrition Study Program, Faculty of Medicine and Health Science, Universitas Kristen Satya Wacana, Jalan Kartini No 11 A, Salatiga, Indonesia

E-mail address: kristiawan.nugroho@staff.uksw.edu 
Antioxidant is an inhibitor compound to obstruct auto-oxidation. Antioxidant is effectives to against many diseases such as carcinogenesis, cardiovascular, and degenerative diseases [4]. Antioxidant has function to neutralize free radical [5]. Free radical is an active oxidant which has at least one or more unpaired electron out of their orbit [6]. Increases immunology status can be done by consumed high antioxidant food.

There are several bioactive substances of Noni fruit that efficacious to the treatment of various diseases, especially for degenerative diseases such as scopoletin, flavonoid and vitamin $\mathrm{C}$. Scopoletin is a phenolic compound that used as an anti-inflammatory, anti-allergic, blood pressure controller, and regulator of glucose levels in the blood [7]. Scopoletin has function to reduce blood pressure with relaxing vascular smooth muscle when arterial blood pressure increases [8]. Another phenolic compound is flavonoid. Flavonoid acted as an antioxidant and anti-cancer. Flavonoid can inhibit chain reaction in the formation of free radicals. Noni also has vitamin $\mathrm{C}$ to improve the immune system [9]. Scopoletin, flavonoid, and vitamin C content can be identified by total phenolic test and total flavonoid test [10].

A lot of people proceed Noni become a food product. The products of Noni are varied such as juice, salad, yogurt, ice cream, coffee and pudding [2]. The way to decrease the bitter taste and the bad smell of Noni fruit was using low temperature process. Low temperature process maintained bioactive substances of Noni as well. The product with low temperature process is pudding. The purpose of this experiments were to determine the antioxidant content of Noni fruit and to find the optimum formulation of Noni pudding seen from sensory characteristics.

\section{Materials and Methods}

This research was using experimental method. The experiment was making pudding with different concentration of Noni extract. Noni extract was added with the concentration of $5 \%$, $10 \%, 15 \%$, and $20 \%$. The materials of this research are Noni juice, milk powder, water, sugar, and agar powder. The equipment were used stainless steel bowl, volumetric flask, spoons, plates, blender, filter, bowl, stove, and pudding cup. The parameters of pudding quality observed are total phenolic assay, total flavonoid assay, and sensory evaluation.

\subsection{Total Phenolic Test}

For making Noni extract, $100 \mathrm{~g}$ of Noni fruit was needed. Noni fruit was cut and blended using blender. The extract was filtered to separate the extract from the pulp. Then pour to a volumetric flask. The method of total phenolic was using Folin-ciocalteau assay to determine the content. The $1 \mathrm{ml}$ extract of Noni and $1 \mathrm{ml}$ of Gallic acid (concentrate version 10, 20, 30, 40, and 50 $\mu \mathrm{g} / \mathrm{ml}$ ) was poured in volumetric flask, which contained with $9 \mathrm{ml}$ of distilled water. Then add 1 $\mathrm{ml}$ of phenol reagent Folin-ciocalteau and mix. Then, the mixture was added with $10 \mathrm{ml}$ of $\mathrm{Na}_{2} \mathrm{CO}_{3} 7 \%$ after 5 minutes. After that, it was incubated for 90 minutes in the room temperature. 
After the incubation, the absorbance of the extract determined with spectrophotometer with an UV-Visible at wavelength $765 \mathrm{~nm}$. Total phenolic expressed in $\mathrm{mg}$ Gallic Acid Equivalent $(\mathrm{GAE}) / \mathrm{g}$ of extract [11].

\subsection{Total Flavonoid Test}

Total flavonoid was determined using colorimetric assay of aluminum chloride $\left(\mathrm{AlCl}_{3}\right)$. The method of the test was mixed $1 \mathrm{ml}$ of Noni extract and standard solution of quercetin (concentrate version 20, 40,60, 80, and $100 \mu \mathrm{g} / \mathrm{ml}$ ) into $4 \mathrm{ml}$ of distilled water on volumetric flask. The mixture was added with $0.30 \mathrm{ml}$ of $\mathrm{NaNO}_{2} 5 \%$ and stayed for 5 minutes. Then, it was added with $0.3 \mathrm{ml}$ of $\mathrm{AlCl}_{3} 10 \%$ and stayed for 5 minutes. After that, the mixture was added with $2 \mathrm{ml}$ of $\mathrm{NaOH} 1 \mathrm{M}$. The absorbance was measured the wavelength $510 \mathrm{~nm}$. Total flavonoid expressed in mg Quercetin Equivalen (QE)/g of extract [11].

\subsection{Formulation of Noni Juice Pudding}

The extract was made by mixing the Noni fruit and water in various rasio according to the trastment (5:95, $10: 90,15: 85$, and $20: 80)$ for making 5\%,10\%,15\%, and $20 \%$ noni fruit extract respectively. Noni fruit and water then were blended. The formulation of pudding was described on the Table 1.

Table 1. Formulation of Noni pudding

\begin{tabular}{lcccc}
\hline \multirow{2}{*}{ Ingredients } & \multicolumn{4}{c}{ Pudding Formulation } \\
\cline { 2 - 5 } & Pudding A & Pudding B & Pudding C & Pudding D \\
\hline Agar powder & $11.25 \mathrm{~g}$ & $11.25 \mathrm{~g}$ & $11.25 \mathrm{~g}$ & $11.25 \mathrm{~g}$ \\
\hline Water & $520 \mathrm{ml}$ & $520 \mathrm{ml}$ & $520 \mathrm{ml}$ & $520 \mathrm{ml}$ \\
\hline Sugar & $100 \mathrm{~g}$ & $100 \mathrm{~g}$ & $100 \mathrm{~g}$ & $100 \mathrm{~g}$ \\
\hline Milk powder & $280 \mathrm{ml}$ & $280 \mathrm{ml}$ & $280 \mathrm{ml}$ & $280 \mathrm{ml}$ \\
\hline Noni extract & $\begin{array}{c}100 \mathrm{ml} \text { of Noni } \\
\text { extract 5\% }\end{array}$ & $\begin{array}{c}100 \mathrm{ml} \text { of Noni } \\
\text { extract } 10 \%\end{array}$ & $\begin{array}{c}100 \mathrm{ml} \text { of Noni } \\
\text { extract } 15 \%\end{array}$ & $\begin{array}{c}100 \mathrm{ml} \text { of Noni } \\
\text { extract 20\% }\end{array}$ \\
\hline
\end{tabular}

\subsection{Sensory Evaluation}

Sensory evaluation used to find the most preferred formulation of Noni juice pudding based on human sensory. Sensory evaluation was conducted by 50 panelists randomly selected. The panelists were asked to respond to likes or dislikes based on the scale of the preference smell, taste, and texture of pudding by filled the sensory assessment form. For the sensory evaluation, the parameter was rate from 1 to 10 . The description showed on the Table 2 . The analysis of sensory evaluation was using Excel.

Table 2. Liker Scale of Sensory Evaluation of Noni Extract Pudding

\begin{tabular}{cc}
\hline Rate & Description \\
\hline $1-2,49$ & Very dislike \\
$2,5-4,49$ & Dislike \\
$4,5-6,49$ & Neutral \\
$6,5-7,99$ & Like \\
$8-10$ & Very like \\
\hline
\end{tabular}




\section{Results and Discussion}

Pudding is a dessert which made by milk and agar powder as the basic ingredients. Pudding is one of food product that categorized as a dessert, which in the production does not require heat treatment, so the antioxidant can be maintained. Flavor addition is the important thing to increase the taste. Therefore, a good formulation was needed to make a tasty food. This research was using Noni fruit extract as a flavor of the pudding.

Noni is a fruit which has a lot of bioactive content with high antioxidant compound. Noni fruit has some antioxidant compounds such as phenol, flavonoid, scopoletin, vitamin $C$, etc $[7,8,9]$. The parameters of pudding quality observed are total phenolic assay, total flavonoid assay, and sensory evaluation.

\subsection{Total Phenolic}

The phenolic and flavonoid compound were determined by total phenolic test and total flavonoid test [12]. Table 3 showed the total phenolic average of Noni juice. It was $31.277 \mu \mathrm{g}$ $\mathrm{GAE} / \mathrm{ml}$. The total phenolic content was $0.13423 \mathrm{mg} \mathrm{GAE} / \mathrm{g}$.

Table 3. The result of total phenolic compound of Noni juice extract

\begin{tabular}{cccc}
\hline Sample & $\begin{array}{c}\text { Average Total } \\
\text { phenol } \\
(\boldsymbol{\mu g ~ G A E} / \mathbf{m L})\end{array}$ & $\begin{array}{c}\text { Extract grade } \\
(\mathbf{m g ~ G A E} / \mathbf{m L})\end{array}$ & $\begin{array}{c}\text { Total phenolic } \\
\text { content } \\
(\mathbf{m g ~ G A E} / \mathbf{g r})\end{array}$ \\
\hline Extract of Noni & 31,277 & 0,31277 & 0,13423 \\
\hline
\end{tabular}

Some researchers said that total phenol of Noni fruit was from 1.426 to $3.647 \mathrm{mg} \mathrm{GAE} / \mathrm{g}$ [13]. The other studies said that total phenolic of Noni fruit ranged from $2.253 \mathrm{mg}$ GAE/g to 2.848 mg GAE/g [14]. A researcher said total phenolic of Noni fruit was $180 \mu \mathrm{g}$ GAE/g [15]. Some researchers claimed that total flavonoid between $0.0017 \mathrm{mg} \mathrm{QE} / \mathrm{g}$ to $0.0137 \mathrm{mg} \mathrm{QE} / \mathrm{g}$ [16].

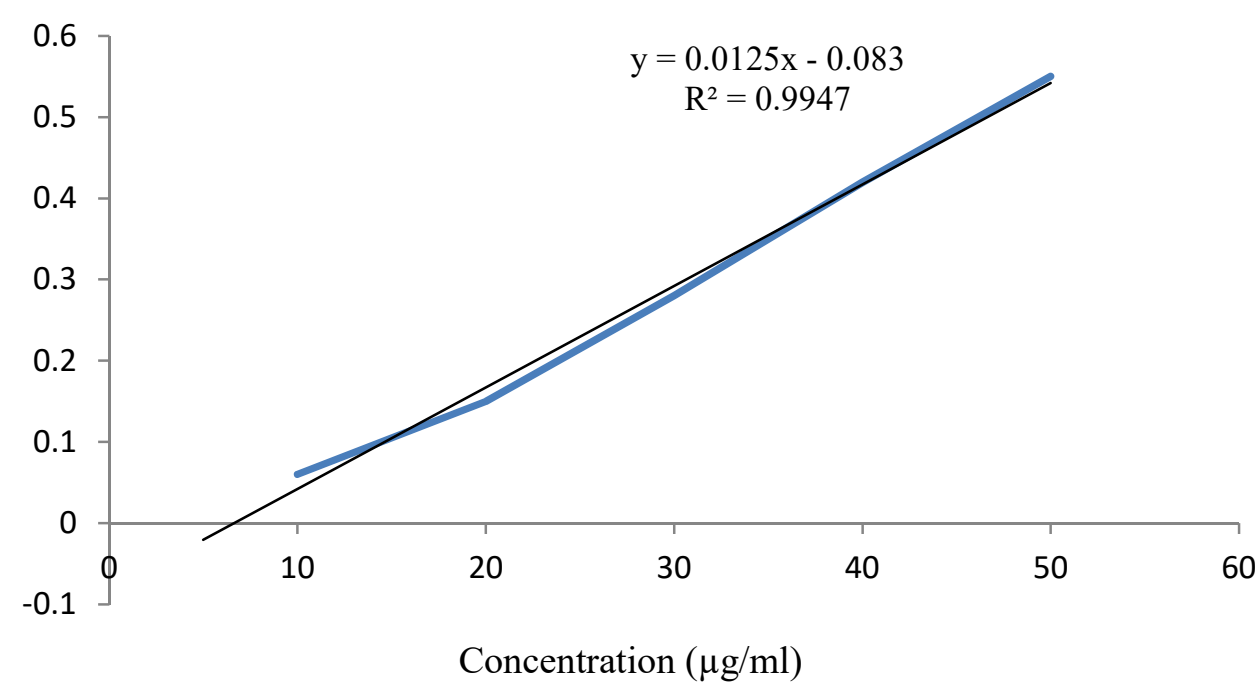

Figure 1. The Graphic of Total Phenolic Content of Noni Juice 
Figure 1 showed the graphic of total phenolic of Noni juice. The graphic showed the absorbance value of the standard Gallic acid solution in each concentration. In the graphic, the standard solution of Gallic acid was in concentrate $10,20,30,40$, and $50 \mu \mathrm{g} / \mathrm{ml}$. The concentration was measured at wavelength $765 \mathrm{~nm}$. The equation obtained from Gallic acid absorbance: $\mathrm{y}=$ $0.012 \mathrm{x}-0.083$ and the correlation coefficient value (r) was 0.994 .

\subsection{Total Flavonoid}

The result of total flavonoid compound test was described on Table 4 and Figure 2. On Table 4 showed that the average of total flavonoids was $27.54 \mu \mathrm{g} \mathrm{QE} / \mathrm{ml}$. Therefore the final result of total flavonoid content of Noni juice was $0.11819 \mathrm{mg}$ QE/g. Based on the other research, the range of flavonoids content in Noni fruit is between $0.0017 \mathrm{mg} \mathrm{QE} / \mathrm{g}$ to $0.0137 \mathrm{mg} \mathrm{QE} / \mathrm{g}$ [14].

Table 4.The result of total flavonoids compound of Noni juice extract

\begin{tabular}{cccc}
\hline Sample & $\begin{array}{c}\text { Average Total Flavonoid } \\
(\boldsymbol{\mu g} \mathbf{Q E} / \mathbf{m L})\end{array}$ & $\begin{array}{c}\text { Extract grade } \\
(\mathbf{m g} \mathbf{Q E} / \mathbf{m L})\end{array}$ & $\begin{array}{c}\text { Total phenolic content } \\
(\mathbf{m g} \mathbf{Q E} / \mathbf{g})\end{array}$ \\
\hline Extract of Noni & 27.54 & 0.2754 & 0.11819 \\
\hline
\end{tabular}

\section{Flavonoid Total}

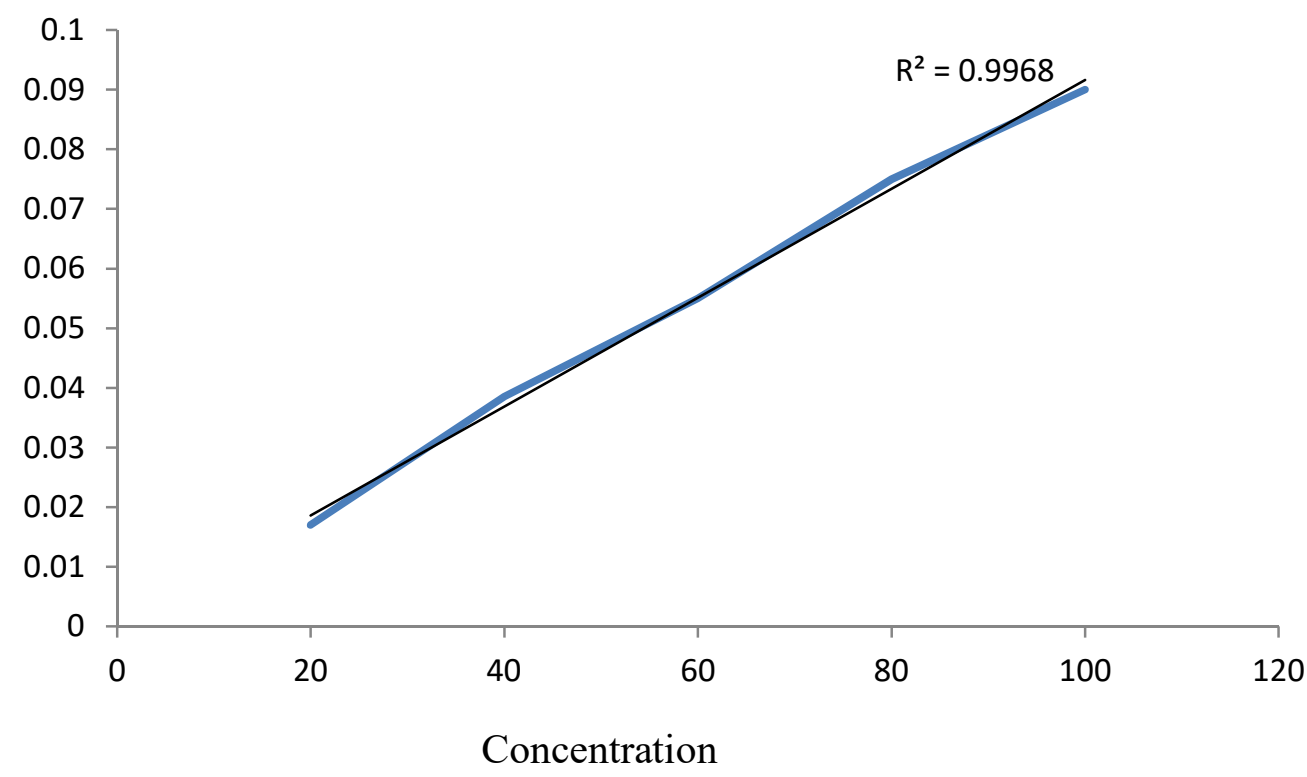

Figure 2.The Graphic of Total Flavonoids Content of Noni Juice

Figure 2 showed the graphic of total flavonoid of Noni fruit. The graphic showed the absorbance value of the quercetin solution in each concentration. In the graphic, the quercetinwas measured at $20,40,60,80$, and $100 \mu \mathrm{g} / \mathrm{ml}$ of solution concentration. The correlation coefficient value (r) was 0.996 .

The results of the total phenol and total flavonoid were different in every research. The differences results of total phenol and total flavonoid of Noni fruit caused of several factors. The 
factors such as the characteristic of Noni, maturity level, temperature, air humidity, soil factors, and sunlight factor [16]. Environmental factors have huge affected for the quality of Noni fruit.

\subsection{Sensory Evaluation}

The formulation was made to determine the preference of the product. The level preferences were using sensory evaluation [17]. Noni is a fruit that less favored by peoples due to the unpleasant aroma and texture. Therefore, by process the Noni fruit into pudding will make everyone easy to consume without eliminating the content on it. Sensory evaluation was obtained by 50 random panelists. The analysis of sensory evaluation was described on graphic 3. The analysis was determined based on aroma, taste and texture of Noni extract pudding. Figure 3 showed the analysis result of sensory evaluation of Noni pudding formulation depend on aroma, taste, and texture. The analysis sensory showed pudding B has higher preferred result.

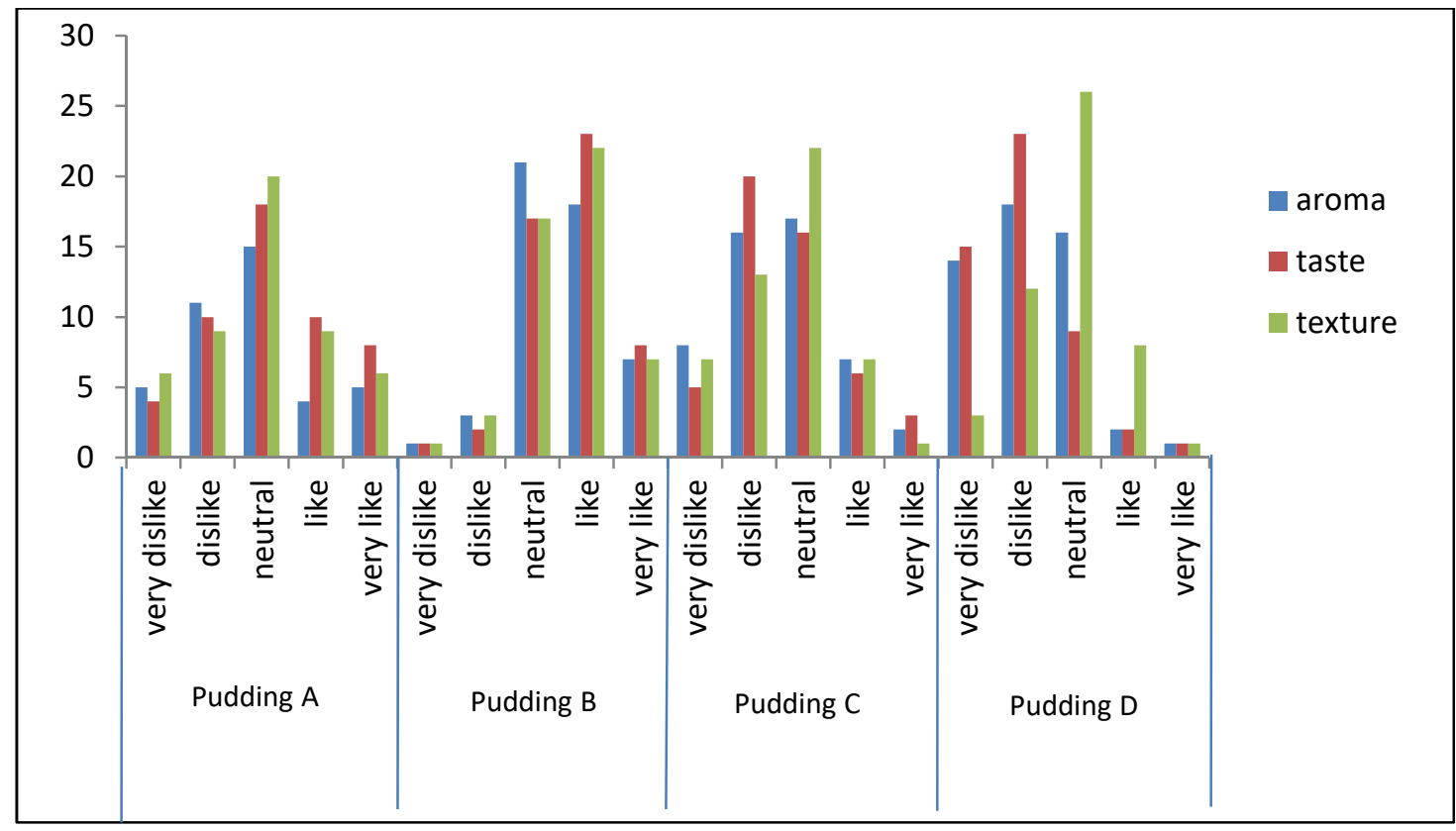

Figure 3. The Graphic Sensory Evaluation Analysis of Noni Extract Pudding Formulation 


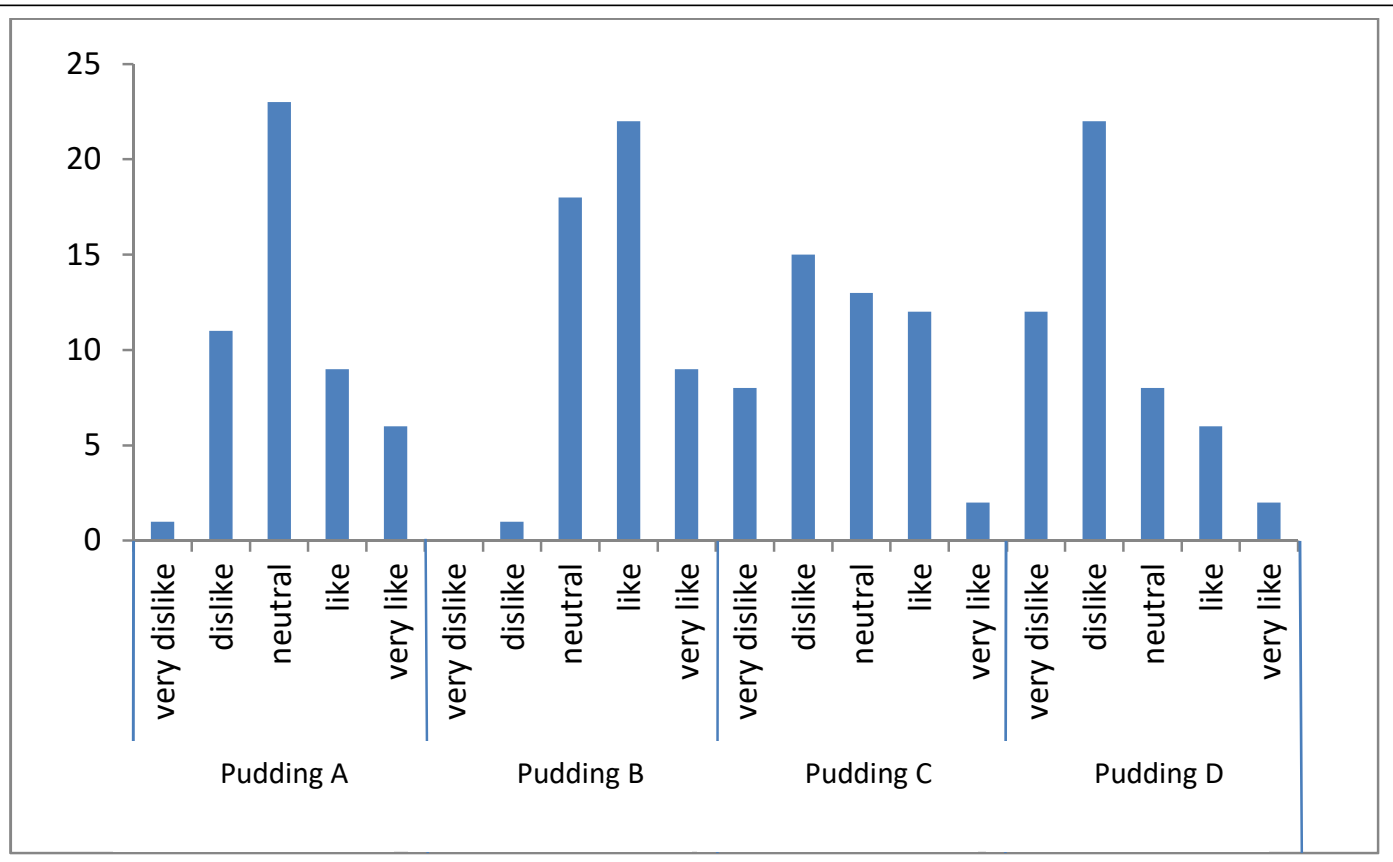

Figure 4. The Graphic of Sensory Evaluation Overall Results of Noni Extract Pudding Formulation

For the overall result of sensory evaluation can be seen at Figure 4. The graphic showed that formulation pudding B has the highest preference result than others. There were $9 \%$ at very like category, $22 \%$ at like category, $18 \%$ at neutral category, $1 \%$ at dislike category, and $0 \%$ at very dislike category. Based on very like category, Figure 4 showed that Pudding B has the most preferred formulation than the others. Pudding D has high result on dislike category. It was $22 \%$ on dislike category. Its mean that almost all of 50 panelists were not interested on pudding D. Pudding A was $23 \%$ on neutral category. Pudding C was $15 \%$ on dislike category.

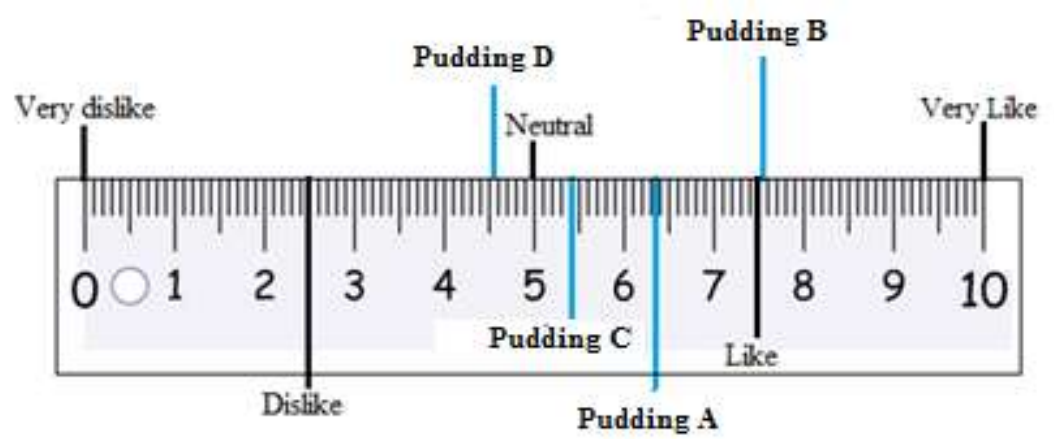

Figure 5. Liker Scale of Noni Pudding Formulation

Liker scale of the pudding formulation can be seen on Figure 5. The result showed that pudding B has preferred rate in 7.56 and categorize as like. Pudding A has preferred rate in 6.32 and categorized as neutral. Pudding $\mathrm{C}$ has preferred rate in 5.4 and categorized as neutral. Pudding $\mathrm{D}$ has preferred rate in 4.56 and categorized as dislike. From 50 panelist preference, Pudding A, pudding $\mathrm{C}$, and pudding $\mathrm{D}$ were on neutral category. Its mean both pudding has the standard taste. Pudding B was on like category. Its mean almost all panelists more prefer to the pudding B formulation. 


\section{Conclusion and Recommendation}

The result showed that Noni fruit has total phenolic was $0.13423 \mathrm{mg} \mathrm{GAE} / \mathrm{ml}$ and total flavonoid was $0.11819 \mathrm{mg} \mathrm{GAE} / \mathrm{mL}$. Pudding B has the higher preferred result based on aroma, taste, and texture. The optimum formulation of pudding resulted from sensory evaluation was found with the addition of $10 \%$ of Noni extract.

\section{REFERENCES}

[1] R. M. Saf-ur, N. Aziz, and A. H. Gilani, "Studies on antidyslipidemic effects of morinda citrifolia (noni) fruit, leaves and root extracts," Lipids in Health and Disease, vol. 9, pp. 88, 2010.

[2] R. P. Putu, P. A. Risa, and Damiati, Studi Eksperimen Pemanfaatan Buah Mengkudu Menjadi Dodol Beraroma Vanili dan Daun Pandan. Universitas Pendidikan Ganesha, 2014, 10.

[3] Bangun and Sarwono, Sehat dengan Ramuan Obat Tradisional Khasiat dan Manfaat Mengkudu. Jakarta: Agro media Pustaka, 2002.

[4] A. Rohman and S. Riyadi, "Aktivitas antioksidan ekstrak buah mengkudu (Morinda citrifolia L.)," Journal of Agritech, vol. 25, no. 3, Universitas Gadjah Mada, 2005.

[5] H. Winarsi. Antioxidant Alami dan Radikal Bebas: Potensi dan Aplikasinya Dalam Kesehatan. Kanisius, 2007.

[6] K. Sayuti and R. Yenrina, Antioksidan Alami dan Sintetik. Asosiasi Penerbit Perguruan Tinggi Indonesia: Andalas University Press, 2015.

[7] Y. S. Cici, "Penggunaan buah mengkudu (Morinda citrifolia L.) untuk menurunkan tekanan darah tinggi," Jurnal Majority, vol. 4, no. 3, 2015.

[8] H. Suidah, "Pengaruh mengkudu terhadap penurunan tekanan darah pada penderita hipertensi di Desa Wedoroklurk Kecamatan Candi Kabupaten Sidoarjo;" Jurnal Keperawatan, vol. 1, no. 1, 2011.

[9] R. F. Ulfah, "Antidiabetic effect of Morinda citrifolia L. as a treatment of diabetes mellitus," Jurnal Majority, vol. 3, no. 7, 2014.

[10] A. Khoerul and T. Liling, "Kandungan total fenolik, total flavonoid, dan aktivitas antioksidan ekstrak etanol buah mengkudu (Morinda citrifolia L.)," Jurnal Pharmascience, vol. 3, no. 1, pp. 83-92, 2016.

[11] J. Biju, C. T. Sulaiman, G. Satheesh, and V. R. K. Kredy, "Total phenolic and flavonoids in selected medicinal plants from kerala," International Journal of Pharmacy and Pharmaceutical Sciences, vol. 6, no. 1, 2014.

[12] M. Jun, H. Y. Fu, J. Hong, X. Wan, C. S. Yang, C. T. Ho "Comparison of antioxidant activities of isoflavones form kudzu root (Puerarua labata O)," Journal Food Science Institute of Technologist, vol. 68, pp. 2117-2122, 2003.

[13] S. B. I. Assanga et al., "Effect of maturity and harvest season on antioxidant activity, phenolic compounds and ascorbic acid of morindacitrifolia 1. (noni) grown in Mexico," African Journal of Biotechnology, vol. 12, no. 29, pp. 4630-4639, 2013.

[14] K. David, "Aktivitas antimikroba dan antioksidan ekstrak tepung daun dan buah mengkudu (Morinda citrifolia)," Jurnal Ilmu Peternakan, vol. 28, no. 2, 2018, pp. 105-111.

[15] Amrianto, Mukarramah, D. S. Dike, N. A. Nurun, and D. P. Andi, "Formulasi ekstrak buah mengkudu (morinda citrifolia) dalam bentuk sediaan transdermal liposome cream," Prosiding Seminar Nasional Biology for Life, 2017. 
[16] S. Deng, B. J. West, and C. J. Jensen, "A quantitative comparison of phytochemical components in global noni fruit and their comercial products," Food Chemistry, vol. 122, no.1, pp. 267-270, 2010.

[17] A. C. Erungan, I. Bustami, and A. N. Yudistira, "Analisis pengambilan keputusan uji organoleptik dengan metode multi kriteria," Jurnal Pengolahan Hasil Perikanan Indonesia, vol. 8, no.1, 2005. 